Discussion Paper No. 08-100

\title{
Initial Risk Matrix, Home Resources, Ability Development and Children's Achievement
}

Dorothea Blomeyer, Katja Coneus, Manfred Laucht, and Friedhelm Pfeiffer

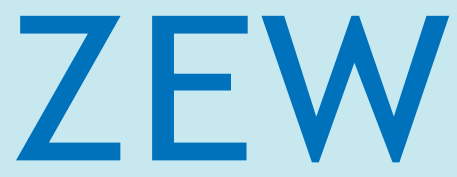

Zentrum für Europäische Wirtschaftsforschung $\mathrm{GmbH}$ Centre for European Economic Research 
Discussion Paper No. 08-100

\title{
Initial Risk Matrix, Home Resources, Ability Development and Children's Achievement
}

\author{
Dorothea Blomeyer, Katja Coneus, \\ Manfred Laucht, and Friedhelm Pfeiffer
}

Download this ZEW Discussion Paper from our ftp server:

ftp://ftp.zew.de/pub/zew-docs/dp/dp08100.pdf

Die Discussion Papers dienen einer möglichst schnellen Verbreitung von neueren Forschungsarbeiten des ZEW. Die Beiträge liegen in alleiniger Verantwortung der Autoren und stellen nicht notwendigerweise die Meinung des ZEW dar.

Discussion Papers are intended to make results of ZEW research promptly available to other economists in order to encourage discussion and suggestions for revisions. The authors are solely responsible for the contents which do not necessarily represent the opinion of the ZEW. 


\section{Nontechnical Summary}

Deep-seated capabilities formed in early childhood, a period of dramatic growth and need for intensive interaction with an "invested adult", may have long-term implications for human development and personality. Human capital research analyzes the relationship between initial risk conditions (from the organic and the psychosocial dimension), investments and ability development to gain an understanding of the formation of competence, both from an economic and a psychological point of view.

Our contribution to this burgeoning multidisciplinary literature on individual development is twofold. First, we present economic models of ability formation with unique data from a developmental psychological approach for the first time. The data are taken from the Mannheim Study of Children at Risk (MARS), an epidemiological cohort study that follows 384 children from birth to adulthood. MARS provides detailed psychometric and medical assessments as well as psychological expert ratings on various child outcome measures. We study data from infancy to adolescence with variables on initial risk conditions, on cognitive and motor abilities, as well as on persistence, a noncognitive ability. Second, we analyse the relationship between economic and socio-emotional home resources and the development of abilities, and investigate the predictive power of abilities acquired at preschool age for children's achievement at school age. This should deepen the understanding of competence formation from both an economic and a psychological perspective.

Results indicate that differences in abilities at infancy increase until adolescence, while there is a remarkable stability in the distribution of the economic and socioemotional home resources during childhood. Initial organic and psychosocial risk conditions trigger a cumulative effect. Persistence fosters cognitive abilities and school achievement. Basic abilities at preschool age significantly predict social competencies and school grades. Higher basic abilities at primary school age and higher home resources predict a higher-track secondary school attendance. Growing up in an unfavourable socio-emotional family environment impedes the development of basic cognitive and motor abilities. The disadvantage continues until school age, an important stage for noncognitive ability formation. Disadvantaged children are impeded again when the transition to higher-track secondary school attendance takes place. At this stage, economic resources create an additional barrier.

We conclude that investment during preschool age bolsters children's cognitive and noncognitive abilities and improves school achievement. Economic support at school age is needed in addition to enter a higher-track secondary school. Future research on competence formation needs to focus on the variety of parental care and its interaction with individual development. 


\section{Das Wichtigste in Kürze}

Im Rahmen des Leibniz Netzwerks „Nichtkognitive Fähigkeiten: Erwerb und ökonomische Konsequenzen“ haben Bildungsforscher des ZEW in Kooperation mit dem Zentralinstitut für seelische Gesundheit (ZI) in Mannheim die Bedeutung der organischen und psychosozialen Geburtsbedingungen für den schulischen Erfolg untersucht. Als Datengrundlage dient die Mannheimer Risikokinderstudie, eine Längsschnittstudie zur Erforschung der Auswirkungen von Geburtsrisiken im Lebenslauf. Diese Untersuchung umfasst 384 erstgeborene Kinder mit deutsch sprechenden Eltern in der Rhein-Neckar-Metropolregion. Die Kinder wurden bei der Geburt nach der Schwere organischer und psychosozialer Risiken ausgewählt. Zu den organischen Risiken zählen unter anderem Geburtskomplikationen, Frühgeburten und (sehr) niedriges Geburtsgewicht. Zu den psychosozialen Risiken zählen unter anderem frühe Elternschaft, mangelnde Bildung der Eltern, sowie (erhebliche) Dissonanzen zwischen den Eltern.

Die Ergebnisse der Studie verdeutlichen, dass die Risken bei der Geburt mit über den Schulerfolg bestimmen. Während 75 Prozent der Kinder, die ohne organische und psychosoziale Risiken bei der Geburt aufwachsen konnten, ein Gymnasium besuchen, trifft das nur für 15 Prozent der Kinder zu, die mit deutlichen Risiken aufgewachsen sind. Bei den Schulnoten in der Grundschule im Alter von acht Jahren haben die Wissenschaftler Unterschiede bis zu einer ganzen Note gefunden. Dabei zeigte sich, dass die psychosozialen Risiken für deutlich schlechtere Schulnoten verantwortlich sind, als die organischen.

Neben den Risiken, die bei der Geburt vorhanden sind, spielt für die Ungleichheit von Fähigkeiten und Bildungschancen die Qualität der elterlichen Fürsorge im Vorschulalter eine wichtige Rolle. In diesem Alter werden die grundlegenden kognitiven Kompetenzen, darunter die Gedächtnisleistung, die Informationsverarbeitung und die logischen Fähigkeiten ausgebildet, die den Erfolg in der Schule befördern. Die Bildung dieser Fähigkeiten wird von der Qualität der elterlichen Fürsorge begünstigt. Im Schulalter wiederum kann fehlendes Geld den Übergang ins Gymnasium behindern. Im Schulalter hat eine niedrige Qualität der elterlichen Fürsorge zudem eine Abnahme nichtkognitiver Fähigkeiten zur Folge. Familiär benachteiligten Kindern fällt es vielfach schwerer, ihre Ziele zu verfolgen und sich dabei nicht ablenken zu lassen. Dies erschwert den Schulerfolg und die Bildungskarriere.

Aus ökonomischer Sicht legen die Ergebnisse der modernen Humankapitalforschung die Schlussfolgerung nahe, dass die Architektur des Bildungssystems in Deutschland eine neue Statik benötigt. Versäumnisse beim Aufbau der grundlegenden Fähigkeiten in der frühen Kindheit können später vielfach nur mit einem erheblichen Aufwand korrigiert werden. Deshalb müssen die öffentlichen Bildungsanstrengungen für benachteiligte Kinder, die bereits in jungen Jahren erheblichen Risikofaktoren ausgesetzt sind, früher als bisher ansetzen. 


\title{
Initial risk matrix, home resources, ability development and children's achievement
}

\author{
Dorothea Blomeyer ${ }^{+}$, Katja Coneus*, Manfred Laucht ${ }^{+}$, Friedhelm Pfeiffer* \\ Central Institute of Menatl Health (ZI), Mannheim \\ *Centre for European Economic Research (ZEW), Mannheim
}

December 4, 2008

\begin{abstract}
:
This paper investigates the development of basic cognitive, motor and noncognitive abilities from infancy to adolescence. We analyse the predictive power of these abilities, initial risk conditions and home resources for children's achievement. Our data are taken from the Mannheim Study of Children at Risk (MARS), an epidemiological cohort study, which follows the long-term outcome of early risk factors. Results indicate that differences in abilities increase during childhood, while there is a remarkable stability in the distribution of the economic and socio-emotional home resources during childhood. Initial risk conditions trigger a cumulative effect. Cognitive, motor and noncognitive abilities acquired during preschool age contribute to the prediction of children's achievement at school age.
\end{abstract}

Keywords: Initial Conditions, Home Resources, Intelligence, Persistence, Social Competencies, School Achievement.

JEL-classification: D87, I12, I21, J13

\section{Acknowledgements:}

We gratefully acknowledge support from the Leibniz Association, Bonn through the grant "Noncognitive Skills: Acquisition and Economic Consequences". Dorothea Blomeyer and Manfred Laucht thank the German Research Foundation and the Ministry of Science and Research for their support in conducting MARS. For their helpful comments, we thank an anonymous referee, Anja Achtziger, Lex Borghans, Liam Delaney, Wolfgang Franz, Bart Golsteyn, James Heckman, Andrea Mühlenweg, Grit Mühler, Pia Pinger, Karsten Reuß, and participants at the Annual Meeting of the European Economic Association 2008. For excellent research assistance, we are grateful to Mariya Dimova and Moritz Meyer. Any remaining errors are our own.

\section{Corresponding author:}

Friedhelm Pfeiffer, Centre for European Economic Research, P.O. Box 103443, D68034 Mannheim. Tel.: +49-621-1235-150, E-mail: pfeiffer@zew.de 


\section{Introduction}

Economists and psychologists share a common interest in the research on ability and health development (Heckman, 2007, 2008). Deep-seated skills are formed in a dynamic interactive process starting in early childhood, and research that is based on only a subset of relevant factors may contain some bias. The relationship between initial risk conditions (both from the organic and the psychosocial perspective), investments and ability development is analysed to gain an understanding of the formation of abilities in childhood.

Our contribution to this burgeoning multidisciplinary literature on individual development is twofold. First, we present economic models of ability formation with unique data from a developmental psychological approach for the first time. The data are taken from the Mannheim Study of Children at Risk (MARS ${ }^{1}$ ), an epidemiological cohort study that follows 384 children from birth to adulthood (Laucht et al., 1997, 2004). MARS provides detailed psychometric and medical assessments as well as psychological expert ratings on various child outcome measures. We study data from infancy to adolescence with variables on initial risk conditions, on cognitive and motor abilities, as well as on persistence, a noncognitive ability. Second, we analyse the relationship between economic and socio-emotional home resources and the development of abilities, and investigate the predictive power of abilities acquired at preschool age for children's achievement at school age. This should deepen the understanding of competence formation from both an economic and a psychological perspective.

There is a significant degree of stability in the economic and socio-emotional home resources over time. This is presumably a major reason for the increase of inequality in development. Disadvantages from adverse home environments can trigger further disadvantages during the developmental stages. In early childhood, the formation of cognitive and motor abilities is hindered. As a consequence, the acquisition of noncognitive abilities at school age is impaired. Children are hindered once again during the transition to a higher-track secondary school, when low economic resources constitute an additional barrier.

\section{Data: Initial risk matrix, home resources, and children's achievement}

MARS aims at following infants at risk for later developmental disorders, in order to examine the impact of initial adverse conditions on the probability of negative health and socio-economic outcomes (Laucht et al. 2004). It includes first-born infants growing up with German-speaking parents in a West German urban conglomeration

\footnotetext{
${ }^{1}$ MARS has been derived from the German title: MAnnheimer Risikokinder Studie.
} 
(the Rhine-Neckar region) of medium size. Infants were rated according to the degree of "organic" risk and the degree of "psychosocial" risk. Each risk factor was scaled as no risk, moderate risk or high risk, as shown in Figure 1. Organic risk factors include conditions such as preterm birth or neonatal complications, while psychosocial risk factors refer to characteristics of adverse home environments, such as low-educated parents, early parenthood, or parents with a mental disorder. According to this rating, children were assigned to one of the nine groups resulting from the two-factor $3 \times 3$ design. $^{2}$ All groups have about equal size, with a slight oversampling in the high risk combinations and with sex distributed evenly in all subgroups.

Figure 1: Initial risk matrix and means of abilities, 3 months and 11 years Psychosocial risk

\begin{tabular}{|c|c|c|c|c|c|c|c|}
\hline \multirow{11}{*}{ 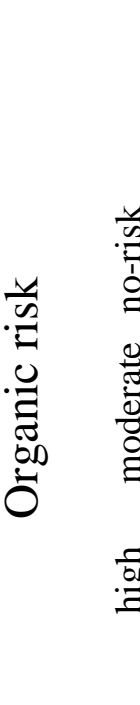 } & \multirow{5}{*}{$\begin{array}{l}I Q \\
M Q \\
P\end{array}$} & no-risk & moderate & high & \multirow{3}{*}{$\begin{array}{r}108^{\star} \\
104^{*} \\
4.8^{*}\end{array}$} & \multirow{3}{*}{$\begin{array}{l}107^{*} \\
106^{*} \\
4.1^{*}\end{array}$} & \multirow{3}{*}{$\begin{array}{l}100^{*} \\
104^{*} \\
3.8^{*}\end{array}$} \\
\hline & & \multirow{4}{*}{$\begin{array}{l}103^{*} \\
103^{*} \\
3.8^{*}\end{array}$} & \multirow{4}{*}{$\begin{array}{l}102 * \\
102 * \\
3.5^{*}\end{array}$} & \multirow{3}{*}{$\begin{array}{l}96 * \\
103^{*}\end{array}$} & & & \\
\hline & & & & & & & \\
\hline & & & & & \multirow{4}{*}{$\begin{array}{l}105^{*} \\
97 * \\
4.0^{*}\end{array}$} & \multirow{4}{*}{$\begin{array}{l}98 * \\
103 * \\
3.9\end{array}$} & \multirow{4}{*}{$\begin{array}{l}97 \\
98 * \\
3.6\end{array}$} \\
\hline & & & & 3.2 & & & \\
\hline & & $101^{*}$ & $99 *$ & $97 *$ & & & \\
\hline & & \multirow{2}{*}{$\begin{array}{l}101^{*} \\
3.5^{*}\end{array}$} & \multirow{2}{*}{$\begin{array}{l}98 * \\
3.4\end{array}$} & \multirow{2}{*}{$\begin{array}{l}99 * \\
3.2\end{array}$} & & & \\
\hline & & & & & \multirow{3}{*}{$\begin{array}{l}101^{*} \\
98^{*} \\
4.0^{*}\end{array}$} & \multirow{3}{*}{$\begin{array}{l}92 \\
97 * \\
3.7\end{array}$} & \multirow{3}{*}{$\begin{array}{l}87 \\
86 \\
3.6\end{array}$} \\
\hline & & 95 & 93 & 88 & & & \\
\hline & & 93 & 92 & 89 & & & \\
\hline & & $3.6^{*}$ & 3.1 & 3.1 & \multicolumn{3}{|c|}{11 years } \\
\hline
\end{tabular}

MARS, 364 observations; $I Q$ and $M Q$ are normalized to mean 100 and SD 15 in the normative group; $P$ varies between $1.0,1.1, \ldots$ (low persistence) and ... 4.9, 5.0 (high persistence). * indicates significant differences relative to the highest-risk group at the $5 \%$ level.

Psychometric assessments of cognitive $(I Q)$ and motor abilities $(M Q)$, were conducted at infancy (3 months), toddlerhood (2 years), preschool age (4.5 years), elementary school age (8 years) and secondary school age (11 years), representing significant stages of child development. Our main dimension of noncognitive abilities, persistence $(P)$, is related to goal shielding in the presence of distractors and obstacles. Assessments are based on parent interviews and behaviour observations by experts, starting at the age of 3 months. In addition, information on school achievement, such as grades at primary school age and the type of secondary school a child attends are taken into account.

\footnotetext{
${ }^{2}$ Details on the initial risk matrix, the psychometric assessments of abilities, competences, as well as home resources are discussed in Blomeyer et al. (2008).
} 
Figure 1 summarizes the means of the abilities $I Q, M Q$ and $P$ in the nine risk groups at the ages of 3 months and 11 years. Table 1 presents their first-order temporal correlations. In line with the literature on risk research (Kazdin et al., 1997) and previous findings from MARS, our results indicate that unfavourable consequences of initial organic and psychosocial risks persist until adolescence. Organic and psychosocial risks have cumulative effects. There is a monotonic decrease in $I Q$ and $M Q$ in both risk dimensions, with increasing differences between the ages of 3 months and 11 years. Organic and psychosocial risk factors exhibit equally negative effects, but are specific to the areas they affect. While psychosocial risks primarily influence cognitive and noncognitive functioning, the impact of early organic risks concentrates on motor and cognitive functioning. Average $P$ decreases monotonically along the two dimensions. There is a $23 \%$ difference between the no risk and the highest risk group of children at the age of 4.5 years (3.8 vs. 3.1, see Figure 1 ).

Figure 2: Initial risk matrix and means of $H$ and $Y, 3$ months and 11 years

Psychosocial risk

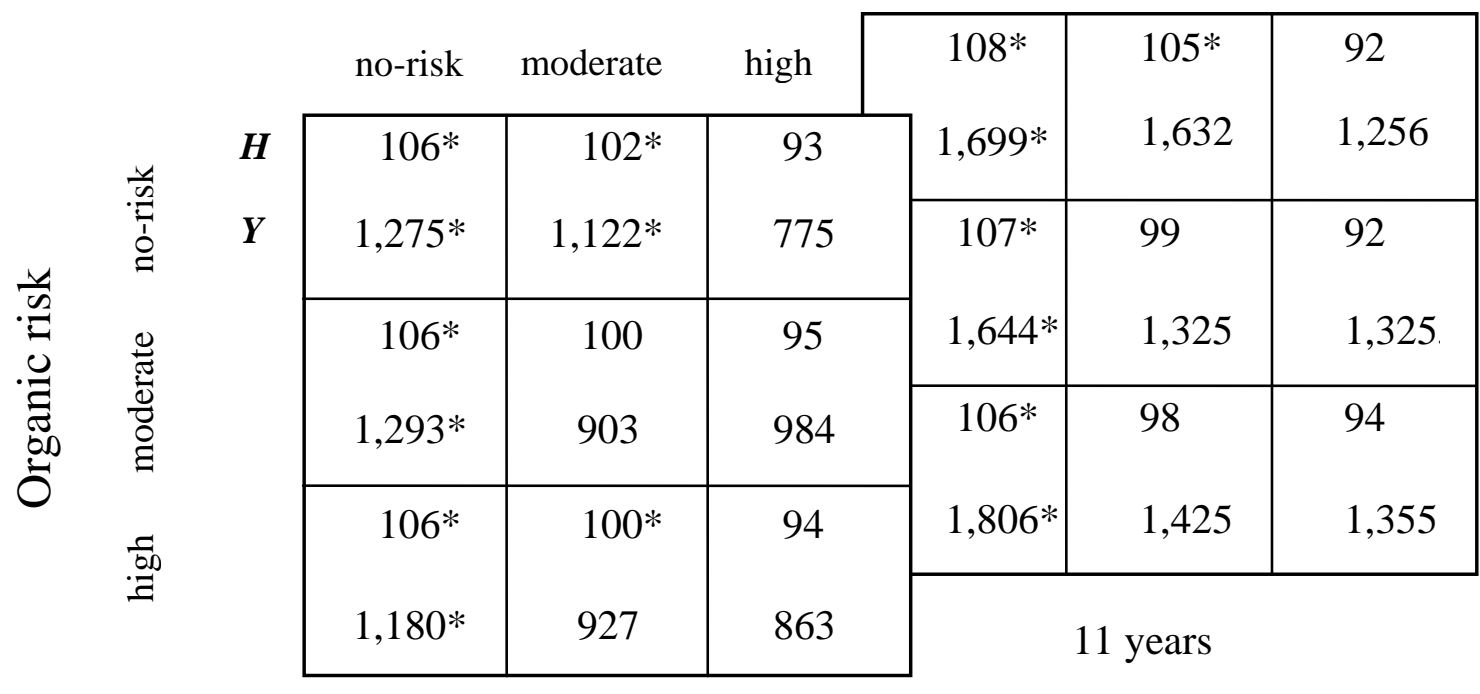

3 months

MARS, 364 observations; $H$ normalized to mean 100 and SD 15 to facilitate comparison; $Y$ : monthly net equivalence income per head in DEM (1 DEM = 0.51129 EUR). * indicates significant differences relative to the highest-risk group at the $5 \%$ level.

Two types of home resources are considered, summarized into socio-emotional categories, $H$, and economic categories, measured as the monthly net equivalence income per household member, $Y$, in Figure 2 and Table 1 . $\mathrm{H}$ was assessed using the Home Observation for Measurement of the Environment (HOME score, Bradley, 1989).

The ratings indicate a considerable longitudinal stability of both home resources (Table 1). $\mathrm{H}$ declines steadily along the psychosocial risk dimension (Figure 2). For 
the group of children with high psychosocial risk, $H$ is $87 \%$ compared to the no risk group, while the value of $Y$ is on average $60 \%$ of the value for the no risk group. The partial elasticity of $H$ with respect to $Y$ varies between 0.06 and 0.11 . If economic resources were doubled, $H$ would be $6 \%$ to $11 \%$ higher.

Table 1: First order temporal correlations in abilities and home resources

\begin{tabular}{ccccc}
\hline \hline & $\begin{array}{c}2 \text { years/ } \\
\text { 3 months }\end{array}$ & $\begin{array}{c}4.5 \text { years/ } \\
\text { 2 years }\end{array}$ & $\begin{array}{c}\text { 8 years/ } \\
\text { 4.5 years }\end{array}$ & $\begin{array}{c}11 \text { years/ } \\
8 \text { years }\end{array}$ \\
\hline \multicolumn{5}{c}{ Abilities } \\
$M Q$ & 0.34 & 0.72 & 0.74 & 0.81 \\
$P$ & 0.35 & 0.63 & 0.53 & 0.60 \\
\hline
\end{tabular}

H: HOME score / Y: monthly net equivalence income per member ${ }^{a}$
$H$
0.78
0.75
0.88
0.93
$Y$
0.82
0.86
0.77
0.79

MARS, 364 observations; ${ }^{a}$ partial correlations from a regression model including a constant; all coefficients are significant at the 5\% level.

\section{The development of abilities}

Abilities develop in a cumulative, dynamic process that has been referred to as the "technology of skill formation" by Cunha and Heckman (2007). Initial conditions, both from the organic and the psychosocial perspective, together with the availability of specific home resources contribute to ability development. Experience in childhood may lay foundations for success or failure in school and for human capital formation in later life. Our epidemiological cohort data allow a detailed look at the initial risk conditions. Moreover, our study contains comprehensive psychometric assessments as well as medical and psychological expert ratings of abilities and specific home resources at significant stages in child development to estimate the parameters of ability development.

The basic structure of the model of Cunha and Heckman (2007) is summarized in equation (1).

$$
\Theta_{t}=f_{t}\left(I_{t}, \Theta_{t-1}, E\right)
$$

$I Q, M Q$ and $P$ at stage $t$ are combined in $\Theta$. Note that the technology, $f$, may also vary with $t$. Other factors included in equation (1) are the initial conditions, $E$, and the economic and socio-emotional home resources, $I$. We are interested in the estimation of the formation process at the major stages of development. Assume that equation (1) can be represented in a Cobb-Douglas form. Taking the natural logarithm yields equation (2): 


$$
\theta_{t, i}^{j}=\alpha_{0, t}^{j, R}+\alpha_{t}^{h, j} \cdot h_{t, i}+\alpha_{t}^{j} \cdot \theta_{t-1, i}^{j}+\alpha_{t}^{k, j} \cdot \theta_{t-1, i}^{k}+\alpha_{t}^{l, j} \cdot \theta_{t-1, i}^{l}+\varepsilon_{t, i}^{j}
$$

where $j, k, l$ are indices for the three abilities $I Q, M Q$ and $P$, and $i=1, \ldots, \mathrm{N}(=364)$ is an index for the children. The variable $R$ contains all nine cells of the twodimensional risk matrix. All parameters can be interpreted as partial elasticity. We focus on the relationship between basic abilities in $t$ with $I$ in period $t$ and the stock of basic abilities available from period $t$ - 1 , taking the initial conditions into account.

The relationship between parental investments and children's abilities may be reciprocal (for a theoretical elaboration on optimal investment over the life cycle see Cunha and Heckman, 2007). Having a child with high cognitive or noncognitive abilities, for instance, is likely to increase $H$ to bolster development. Having a child with low abilities may be a source of stress for the parents, which may even lead to a reduction of $H$. Reciprocity may create bias in the estimates. To address the issue of endogeneity of $H$ we compare OLS with Two Stage Least Square results (TSLS) and use the permanent $Y$ as an instrument for $H$ (see Table 2). Instead of $Y$ we calculate the permanent $Y$ from the available waves, which is more attractive than a wavespecific measure of $Y$ from an investment perspective. $Y$ may contain some temporary fluctuations that are less relevant for investment decisions. Permanent $Y$ is partially related to $H$, one necessary condition for an instrumental variable. We find significant partial correlations in each period $\left(t_{1}=0.06, F\right.$-test $=37.51 ; t_{2}=0.09$, 43.68; $t_{3}=0.11,114.0 ; t_{4}=0.08,82.09$ and $\left.t_{5}=0.07,102.74\right)$. The $F$-statistics indicate that there is no weak instrument problem.

A second condition for $Y$ being a valid instrument is that it should only affect abilities through its relation with $H$. As the exogeneity of an instrument is not testable for the one-instrument case, we assume that the emotional environment of the child does not depend on economic resources, but is mainly driven by parents' attitudes towards the child's development (a direct pathway from $Y$ to children's further achievement might become more relevant after the age of 10 years, see section 4). Indeed, the influence of $Y$ on children's abilities is not significant when we include $H$ in OLS estimates. However, $H$ is significantly related to abilities at all stages, as is shown in Table 2.

The strength of the relationship differs between the three abilities and changes in a way specific to the developmental stage. TSLS estimates for $H$ are higher compared to the OLS estimates, specifically during childhood for the $I Q$. This finding suggests that children with higher (lower) cognitive abilities receive more (less) socioemotional support from their parents. If this interpretation is appropriate OLS would underestimate the partial elasticity of $H$ due to simultaneity. $H$ would be even more important than OLS results indicate. 
Table 2: The partial elasticity of $\mathrm{H}$ and the stock of abilities

\begin{tabular}{|c|c|c|c|c|c|}
\hline Ability & $I Q(t-1)$ & $M Q(t-1)$ & $P(t-1)$ & $H(t)$ & TSLS: $Y$ \\
\hline \multicolumn{6}{|c|}{$t=11$ years } \\
\hline$I Q(t)$ & $0.89 *$ & $0.13 *$ & $0.10^{*}$ & 0.17 & -0.56 \\
\hline$M Q(t)^{a}$ & $0.34^{*}$ & $0.66 *$ & -0.01 & 0.13 & 0.46 \\
\hline$P(t)$ & $0.31 *$ & 0.03 & $0.31^{*}$ & $0.28 *$ & 0.83 \\
\hline \multicolumn{6}{|c|}{$t=8$ years } \\
\hline$I Q(t)$ & $0.84 *$ & $0.26 *$ & 0.07 & 0.19 & 0.43 \\
\hline$M Q(t)^{a}$ & 0.00 & $0.42 *$ & 0.01 & 0.12 & -0.77 \\
\hline$P(t)$ & $0.27^{*}$ & $0.20 *$ & $0.29 *$ & $0.43 *$ & 0.65 \\
\hline \multicolumn{6}{|c|}{$t=4.5$ years } \\
\hline$I Q(t)$ & $0.53 *$ & $0.09 *$ & 0.02 & $0.38 *$ & $0.53^{*}$ \\
\hline$M Q(t)^{a}$ & $0.26 *$ & $0.72 *$ & $0.11^{*}$ & 0.04 & -0.18 \\
\hline$P(t)$ & $0.61^{*}$ & -0.04 & $0.18^{*}$ & $0.50 *$ & -0.09 \\
\hline \multicolumn{6}{|c|}{$t=2$ years $^{a}$} \\
\hline$I Q(t)$ & $0.53^{*}$ & $0.09 *$ & 0.02 & $0.38^{*}$ & $1.52 *$ \\
\hline$M Q(t)$ & $0.26^{*}$ & $0.72 *$ & $0.11^{*}$ & 0.00 & 0.48 \\
\hline$P(t)$ & $0.61^{*}$ & -0.04 & $0.18^{*}$ & $0.37 *$ & $1.27^{*}$ \\
\hline$I Q(t)$ & \multicolumn{3}{|c|}{$\begin{array}{c}\left(0.12 *, 0.10 *, 0.04,0.11 *, 0.10^{*}, 0.02\right. \\
0.07,0.09 *)^{b}\end{array}$} & $0.55^{*}$ & $2.36^{*}$ \\
\hline$M Q(t)^{a}$ & \multicolumn{3}{|c|}{$\begin{array}{c}\left(0.14^{*}, 0.11^{*}, 0.03,0.13^{*}, 0.08^{*}, 0.02\right. \\
\left.0.15^{*}, 0.10^{*}\right)\end{array}$} & 0.16 & -0.18 \\
\hline$P(t)$ & \multicolumn{3}{|c|}{$\begin{array}{c}(0.02,0.07,0.06,0.06,0.09 *, 0.03 \\
0.05,0.08)\end{array}$} & $0.29 *$ & 0.69 \\
\hline
\end{tabular}

MARS, 364 observations; regressions include a constant and are conducted for each ability; heteroscedastically robust standard errors; ${ }^{a}$ the estimation equations for 2 years additionally contain indicator variables for belonging to a cell in the initial risk matrix, as is the case for the $M Q$ equation at $4.5,8$ and 11 years; ${ }^{b}$ describes the degree of organic and psychosocial risk: $(0,0),(1,0)$, $(2,0),(0,1),(1,1),(2,1),(0,2),(1,2),(2,2) ; *$ indicates significance at the 5 percent level. 
However, there are two caveats. First, the TSLS estimates produce high SD (for the year 4.5 and the $I Q$ equation the estimate is 0.53 with SD 0.18 compared to OLS: $0.38,0.7)$. Therefore, the difference to OLS is not always well-determined. In fact, OLS results with low SD may be closer to the "true" parameters of the technology of ability formation. Second, identifying the channels through which interaction takes place in social reality remains a question for future research. In our data, the time variation of $H$ and $Y$ is lower compared to the time variation of the abilities. Therefore, the main direction will be from $H$ to abilities, especially during childhood (the period that we are interested in). Furthermore, it seems that some parents try hard to compensate for low abilities. Section 2, for instance, indicated that for the group of children without any psychosocial risk, there is no difference in $H$ with regard to organic risk. Parents seem to put effort into helping their children if these were exposed to organic risk during birth. The next section shows that this effort improves school achievement.

The goal of the current paper is to estimate stage specific parameters of the technology of ability formation from birth until the age of 11, based on psychometric assessments. From the comparison discussed above and further regressions (available upon request, see Blomeyer et al., 2008) we conclude that the OLS estimates presented in Table 2 are robust. However, we refrain from interpreting the findings in a causal way, for reasons presented above.

In what follows, we concentrate on OLS results. Cognitive and noncognitive abilities are significantly related to the socio-emotional home resources, while the basic motor ability is not. $P$ is significantly associated with $H$ throughout developmental stages until age 8 , with the estimated partial elasticity varying around 0.4 . IQ, however, is positively related to $H$ only until the age of 4.5 years, with an estimated partial elasticity varying around 0.4 . At school age, the elasticity drops to 0.18 and is no longer significant. The partial elasticity of the past and the current $I Q$ increases steadily. This indicates that self-productivity (a term introduced by Cunha and Heckman, 2007) increases steadily. In early childhood, the partial elasticity is still small (relative to the partial elasticity of $H$ ). At primary school age, the relationship between cumulative abilities and $I Q$ is already high. Individual differences in the $I Q$ become stable or consolidate between the age of 5 and 8 years. At the age of 8 years, the estimate approaches 0.9, comparable to the results from Cunha and Heckman (2008).

The results for $M Q$ are different. The partial elasticity of $H$ with respect to motor abilities never reaches significance. The estimates of the partial elasticity of the past and the current $M Q$ are higher compared to those for $I Q$. $M Q$ seems to solidify even faster. Moreover, initial risk conditions remain relevant for the level of $M Q$.

Note that the partial elasticity of the past and the current $P$ shows a different pattern with lower values at all developmental stages. A confirmation of this finding is that the partial elasticity of $H$ with respect to $P$ also remains significant at primary and 
secondary school age. In other words, noncognitive abilities remain malleable during adolescence (Heckman, 2007, Borghans et al., 2008). We find evidence for synergies in ability formation among $P$ and $I Q$. Since the $I Q$ seems to consolidate between the ages of 4.5 and 8 years, insufficient socio-emotional home resources in early childhood are particularly harmful for human capital formation.

\section{Abilities as predictors of children's school achievement}

Do abilities acquired during childhood predict children's achievement at school? In this section we investigate the predictive power of abilities gained at preschool age for grades in maths in primary schools (at the age of 8). In addition, we examine the predictive power of abilities gained up to the age of 8 years with respect to the likelihood of attending a "Gymnasium", the highest high school track in the German education system (this is the academic track, a college/university entry requirement). The entry in Gymnasium takes place, as a rule, after the age of ten.

Our discussion starts with findings from the initial risk matrix. School achievement at the age of 8 years confirms the importance of the initial risk conditions. Average grades in maths vary with the cells of the risk matrix. In the group of children with high psychosocial and high organic risk, average grades in maths are 2.9 (in Germany, grades vary from 1: excellent, to 6 : insufficient). The value is about one grade lower compared with the no risk group (2.1). Parental investments seem to compensate for some of these risks improving school achievement. The share of children attending the Gymnasium differs in the initial risk matrix. Among children with high psychosocial and high organic risk, only 15\% attend the Gymnasium compared to $74 \%$ in the group of children with no risk. There is no difference between the children born with no or only moderate psychosocial risk, if they are not affected by organic risks.

Table 3 presents the findings from multivariate estimates of the determinants of grades in maths at age 8 and of the probability of attending the Gymnasium after the age of 10. In both equations, the stage-specific home resources $H$ and $Y$ are included. The results from two different estimates are presented. One of these includes all available lags of the abilities (columns (2) and (4)) to reduce a potential omitted variables bias, the other (columns (1) and (3)) does not. Using all lags slightly reduces our ability coefficients. Therefore, the bias from omitted variables seems to be rather small.

All variables have been transformed to natural logs allowing a partial elasticity interpretation. The estimates reveal that $I Q, M Q$ and $P$ significantly predict school achievement at the age of 8 and Gymnasium attendance after the age of 10 . Cognitive abilities are more important than noncognitive abilities in both equations. Interestingly, neither $H$ nor $Y$ seems to significantly enhance grades in maths at primary school age. However, both home resources significantly increase the probability of 
attending the Gymnasium. For higher secondary school attendance, the economic resources $Y$ now become relevant (in addition to $H$ and the cumulated abilities).

Table 3: Predicting grades in maths at the age of 8 and Gymnasium attendance after the age of 10

\begin{tabular}{ccccc}
\hline \hline & \multirow{2}{*}{ grades in maths at the age of 8} & \multicolumn{2}{c}{ average marginal probability of } \\
& basic & add. lags $^{a}$ & basic & add. lags $^{a}$ \\
\hline$H(t)$ & -0.49 & -0.44 & $0.82^{*}$ & $0.60^{*}$ \\
$Y(t)$ & -0.04 & -0.03 & $0.15^{*}$ & $0.18^{*}$ \\
$I Q(t-1)$ & $-0.66^{*}$ & $-0.59^{*}$ & $1.03^{*}$ & $0.84^{*}$ \\
$M Q(t-1)$ & -0.10 & -0.18 & $0.37^{*}$ & $0.33^{*}$ \\
$P(t-1)$ & $-0.25^{*}$ & $-0.22^{*}$ & $0.49^{*}$ & $0.38^{*}$ \\
\hline Pseudo $R^{2}$ & 0.17 & 0.32 & 0.29 & 0.32 \\
Observations & 327 & 327 & 357 & 357 \\
\hline \hline
\end{tabular}

MARS, note that a negative coefficient in the grades equation implies a better grade; ${ }^{a}$ the specification contains all available additional lags in abilities, albeit not reported here; these lags are jointly significant (LR-tests: 86.18*, 71.35*); * indicates significance at the $5 \%$ level.

We conclude the section with numerical assessments of the relative role of investments in early childhood and at school age for Gymnasium attendance based upon our estimates (Tables 2 and 3; for a theoretical analysis of optimal investment, see Cunha and Heckman, 2007 and for an application over the life-cycle, see Pfeiffer and Reuß, 2008). Assume that the government would like to improve children's abilities and increase the share of children entering the Gymnasium. The government is willing to raise $Y$ for all households by $10 \%$ (that is 103 DEM in nominal terms $1986 / 1987,1^{\text {st }}$ wave, 151 DEM in nominal terms $1997 / 1998,5^{\text {th }}$ wave). We further assume that an increase in $Y$ by $10 \%$ increases $\mathrm{H}$ by an average of $1 \%$ (see section 3 for the empirical relationship).

A 10\% increase of $Y$ implemented when the child is 11 years old would increase the probability of attending the Gymnasium by $1.8 \%$ see Table 3 , column (5)), without any relationship with abilities. If the improvement of economic home resources is performed earlier it would only work indirectly through $H$. In that case, (taking into account all direct and indirect multiplier and accelerator effects, with all abilities and throughout all waves, calculated from Table 2) the gain would be $1.18 \%$ if $Y$ is increased at 3 months, $1.07 \%$ if at 2 years, $0.93 \%$ if at 4.5 years and $0.37 \%$ if at 8 years. If $Y$ is increased each wave during childhood (until the age of 4.5 years) the probability would increase by $(1.18+1.07+0.93=) 3.18 \%$. In addition, children's abilities would be higher. The $I Q$, for instance, would have gained on average by $3.86 \%$ until the age of 11 years. We conclude that investment during preschool age bolsters children's cognitive and noncognitive abilities and improves school 
achievement. Economic support at school age increases the probability to enter Gymnasium in addition.

\section{Concluding remarks}

This paper analyses the development of abilities, starting in infancy, and their predictive power for children's achievement at school age. Our epidemiological cohort data, taken from the Mannheim Study of Children at Risk (MARS), allow for a detailed look at the initial risk conditions. In addition, the data contain comprehensive psychometric and medical assessments, as well as psychological expert ratings of abilities and specific home resources at significant stages of child development.

Growing up in an unfavourable environment impedes the development of basic cognitive and motor abilities. The disadvantage continues until school age, an important stage for noncognitive ability formation. Disadvantaged children are impeded again when the transition to higher-track secondary school attendance takes place. At this stage, economic resources create an additional barrier. Future research on competence formation needs to focus on the variety of parental care and its interaction with individual development. 


\section{References}

Blomeyer, Dorothea, Katja Coneus, Manfred Laucht and Friedhelm Pfeiffer (2008), "Self-productivity and Complementarities in Human Development: Evidence from the Mannheim Study of Children at Risk", ZEW Discussion Paper No. 08067, Mannheim.

Borghans, Lex, Angela L. Duckworth, James J. Heckman, and Bas ter Weel (2008). "The Economics and Psychology of Personality Traits." Journal of Human Resources, 43 (4), 972-1059.

Bradley, Robert H. (1989). "The Use of the HOME Inventory in Longitudinal Studies of Child Development.” in: Marc H. Bornstein, and Norman A. Krasnegar (Eds.), Stability and Continuity in Mental Development: Behavioral and Biological Perspectives. Hillsdale, New Jersey: Lawrence Erlbaum, 191-215.

Cunha Flavio, and James J. Heckman (2008). "Formulating, Identifying and Estimating the Technology of Cognitive and Noncognitive Skill Formation.” Journal of Human Resources, 43 (4), 738-782.

Cunha, Flavio, and James J. Heckman (2007). "The Technology of Skill Formation.” The American Economic Review, 97 (2), 31-47.

Heckman, James J. (2007). "The Economics, Technology and Neuroscience of Human Capability Formation." Proceedings of the National Academy of Sciences, 104 (3), 132250-5.

Heckman, James J. (2008). "The Economics and Psychology of Inequality and Human Development.” Marshall Lecture, Annual Meeting of the European Economics Association, Milano.

Kazdin, Alan E., Helena C. Kraemer, Ronald C. Kessler, David J. Kupfer, and David R. Offord (1997). "Contributions of Risk-factor Research to Developmental Psychopathology.” Clinical Psychology Review, 17 (4), 375-406.

Laucht, Manfred, Günter Esser, and Martin H. Schmidt (1997). "Developmental Outcome of Infants Born with Biological and Psychosocial Risks.” Journal of Child Psychology and Psychiatry, 38, 843-854.

Laucht, Manfred, Martin H. Schmidt, and Günter Esser (2004). “The Development of At-Risk Children in Early Life.” Educational and Child Psychology, 21 (1), 20-31.

Pfeiffer, Friedhelm, and Karsten Reuß (2008). “Age-Dependent Skill Formation and Returns to Education.” Labour Economics, 15 (4), 631-646. 